\title{
Testing Purchasing Power Parity (PPP) to Examine Economic Openness of Turkey Economy: 1958-2018
}

\author{
Nurul Mohammad Zayed ${ }^{1, *}$, Sheikh Abdul Kader ${ }^{2}$, Kisor Ray ${ }^{3}$, Shahiduzzaman Khan Shahi ${ }^{1}$, Arafat \\ Hosain Neloy ${ }^{4}$ \\ ${ }^{1}$ Department of Real Estate, Daffodil International University, Dhaka, Bangladesh. \\ ${ }^{2}$ Department of Economics, Faculty of Social Sciences, Jagannath University \& PhD Scholar, Sakarya University, Turkey. \\ ${ }^{3}$ Techno India University, Kolkata, West Bengal, India. \\ ${ }^{4}$ Department of Business Administration, Daffodil International University, Dhaka, Bangladesh.
}

How to cite this paper: Nurul Mohammad Zayed, Sheikh Abdul Kader, Kisor Ray, Shahiduzzaman Khan Shahi, Arafat Hosain Neloy. (2020) Testing Purchasing Power Parity (PPP) to Examine Economic Openness of Turkey Economy: 1958-2018. Journal of Humanities, Arts and Social Science, 4(2), 143-148.

DOI: $10.26855 /$ jhass.2020.07.008

Received: September 2, 2020

Accepted: October 2, 2020

Published: November 12, 2020

${ }^{*}$ Corresponding author: Nurul Mohammad Zayed, Department of Real Estate, Daffodil International University, Dhaka, Bangladesh.

Email: Zayed.bba@daffodilvarsity.edu.bd

\begin{abstract}
This paper tests Purchasing Power Parity (PPP) with a variant of the Vector Error Correction Model (VECM) which conjectures that an association exists among Real Exchange Rate, Interest Rate, and Inflation rate in Turkey. The target goal of this examination is to research to what extent the chosen macroeconomic factors affect the Real Exchange Rate of Turkey by utilizing the Johansen long-run testing approach to deal with co-integration. The paper demonstrates spellbinding measurements. This paper tried the ADF Unit Root test for demonstrating whether board information is fixed or not. By testing the Johansen test for co-integration the paper demonstrates the relationship between Real Exchange Rate, Interest Rate, and Inflation Rate in Turkey. Vector Error Correction Model (VECM) is likewise evolved to test the short-run elements of the Real Exchange Rate work. Cumulative Sum (CUSUM) and Cumulative Sum of Square (CUSUMQ) have been utilized to test the strength of the model. The outcomes show that there is a short-run and long-run relationship among Real Exchange Rate, Inflation Rate, and Interest Rate. The outcomes indicated that the Inflation Rate negatively affects the Real Exchange Rate, however, Interest Rate has a Positive Impact. Also, the Inflation Rate has a free causal relationship with Real Exchange Rate, however, Interest Rate has a unidirectional relationship. This paper recommends the possibility to improve their Real Exchange Rate by diminishing the Inflation Rate and expanding the Interest Rate.
\end{abstract}

\section{Keywords}

Turkey, PPP, ADF, Unit Root, VECM, Regression, Johansen test, CUSUM, CUSUMQ, Exchange Rate, Inflation Rate, Interest Rate

\section{Introduction}

Purchasing Power Parity (PPP) is a notable non-traditional hypothesis of Macroeconomics. It is an estimation of a particular decent cost in various territories. It's deliberate the estimation of various region's exchange rate. Purchasing Power Parity relies upon a particular nation's inflation rate, interest rate. Turkey is a developed nation and progressively their Purchasing Power Parity is diminishing a result of its inflation rate and interest rate increment step 
by step. The inflation rate is the rate at which money is discounted during a period. Also, the interest rate is the amount of bank charges for the direction of the advantages unveiled as a level of the head. Besides the exchange rate is the value of one currency interims of another currency. This paper is based upon Turkey purchasing power parity where the variable Dependent is the Exchange Rate and the Independent variables are Inflation Rate and Interest Rate. The inflation rate and interest rates are markers of the conversion standard. Turkey's exceedingly free-showcase and their economy is expanded, which is driven by its modern division and administration segments and they have enough assets and capacity to direct their buying power.

\section{Literature Review}

Sayyan (2005) has considered whether the PPP theory is legitimate by utilizing the Vector Error Correction Model and the co-integration test by taking the month to month information from the time of 1982-2004 in Turkey. It is legitimate as indicated by the outcome. Alba (2005) inspected long-run purchasing power parity utilizing a board Unit Root test in the US dollar real exchange rate of 84 developed and developing nations and researched the legitimacy of the PPP theory for the period 1976-2002. As indicated by their decision, PPP is legitimate in Europe and Latin America, it is invalid in Africa and Asia. Çağlayan (2006) has examined the PPP theory by utilizing the Unit Root test and Error Correction Model for Turkey and the United Kingdom somewhere in the range of 1995 and 2004. As per the outcome they acquired, it is invalid. Basher (2007) has analyzed whether the real exchange rate is steady by utilizing Unit Root tests for 17 nations of Organisation for Economic Co-operation and Development (OECD). They took note of information for the period 1973: Ql-1998Q4. Thus, it is presumed that the PPP speculation is substantial. P. K. Narayan et al. (2009) inspected the period somewhere in the range of 1973 and 2002. Thus, the PPP theory of 14 nations is substantial. Tatoğlu (2009) analyzed the legitimacy of the PPP speculation utilizing board Unit Root tests for 25 nations of Organisation for Economic Co-operation and Development (OECD) utilizing information for 1977-2004. The PPP speculation is substantial. Yildırım (2017) mentioned in the Cntral Bank Review of Turkey that the experimental outcome uncovers that nonlinear Unit Root tests convey more grounded proof for the PPP speculation when contrasted with the regular Unit Root test only if nonlinearities in the real exchange rate are effectively indicated. Hüseyin Kalyoncu et al. (2010) utilizing official and bootleg market real exchange rates information from thirteen MENA nations analyzed over the period 1970-1998 to test for proof of PPP. The PPP remains constant for ten nations out of thirteen nations. Joseph D. Alba et al. (2005) and their discoveries demonstrate that PPP holds for the lira-mark exchange rate in one limit system however not in another. Ismail Cevis et al. (2015) utilized the cointegration test to look at the legitimacy of PPP for the delicate five utilizing information from, accordingly, the PPP is substantial in India, Brazil, South Africa, and Turkey. Ümit (2016) explored the legitimacy of PPP for the period somewhere in the range of 2003:01 and 201 S: 10. Thus, the PPP theory is invalid for South Africa and India. Cuestas (2013) researched whether the PPP theory in the Organisation for Economic Co-operation and Development (OECD) nations is legitimate for the period 1972:01-2010:01 by utilizing the direct and nonlinear Unit Root test. As per the experimental outcomes, while it is legitimate in 11 nations, it is invalid in Turkey. Dornbusch (1985) finished up with an audit of the ramifications of PPP inconsistencies which is an application to universal genuine salary correlations, loan fee linkages, and conversion standard approach. Chi-Wei Su et al. (2012) analyzed both straight and nonlinear Unit Root tests with fixed covariates to test the legitimacy of long-run purchasing power parity for the BRICS nations from 1996 to 2010. The outcomes show that PPP remains constant for all BRICS nations.

\section{Objectives}

The purpose of the study is to explore the factors that influence PPP in Turkey on the basis of VECM by employing the Johansen long-run testing approach to co-integration in order to determine the potential effects in the relationship between Real Exchange Rates, Inflation Rate, and Interest Rate thereby estimating how Real Exchange Rates respond to changes in Inflation Rate and Interest Rate. Evaluating the stability of Real Exchange Rates in Turkey and recommend policy guidelines are to improve trade balance deterioration in Turkey.

\section{Methodology}

This paper is based on time series data which is quantitative and qualitative in nature. Secondary data is collected from different sources. Various tests have been used to determine the quality of data and find out the ultimate objective of this paper. The ADF test has been driven to examine the stationary state of the data set. The Johansen test 
has been applied to determine the long-term, short term, and nominal relationship among variables (Real Exchange Rate, Inflation Rate, and Interest Rate). VECM, CUSUM, and CUSUMQ tests have been applied to test the stability of the relationships among variables. Granger Causality is used to indicate a way to investigate causality between two variables in a time series or to identify one time series which is useful to anticipate another.

\section{Results \& Discussions}

The Augmented Dicky Fuller (ADF) Unit Root test shows that the null hypothesis was failing to reject. As (Table 1) the test statistics (3.25) are greater than the critical test at the $5 \%$ level (2.91) this means the data are stationary. Therefore, those do not have a trend or seasonal effects.

Table 1. Augmented Dicky Fuller (ADF) Unit Root Test

\begin{tabular}{|c|c|c|c|}
\hline \multicolumn{4}{|c|}{ Null Hypothesis: D (Real Exchange Rate, 2) has a unit root } \\
\hline \multicolumn{4}{|c|}{ Exogenous: Constant } \\
\hline \multicolumn{4}{|c|}{ Lag Length:1 (Automatic-based on SIC, maxlag = 10) } \\
\hline & & t-Statistic & Prob.* \\
\hline \multicolumn{2}{|c|}{ Augmented Dickey-Fuller test statistic } & 3.25 & 1.00 \\
\hline \multirow[t]{3}{*}{ Test critical values: } & $1 \%$ level & -3.55 & \\
\hline & $5 \%$ level & -2.91 & \\
\hline & $10 \%$ level & -2.59 & \\
\hline & 96) one-sidec & & \\
\hline
\end{tabular}

Source: Estimated.

The Johansen test (Table 2) illustrates that there is a long-term relationship where at most one co-integration equation exists. The trace value of the null hypothesis at most 1 is (14.85) which is less than 0.05 critical values (15.49). In the long run normalized co-integration (Table 3) shows the Inflation Rate has a Negative Impact, whereas the Interest Rate has a Positive Impact. The coefficient is statistically significant at the $1 \%$ level.

Granger causality test (Table 4) shows three causalities between the variables:

- "Inflation Rate does not granger cause Real Exchange Rate" is not rejected because the probability value is more than 0.05 and the same for the "Real Exchange Rate to Inflation (Independent Relationship)".

- "Interest Rate does not granger cause Real Exchange Rate" is not rejected because probability value is more than 0.05 (Independent Relationship).

- "Interest Rate does not granger cause Inflation Rate" is not rejected but "Inflation Rate does not granger cause Interest Rate" is rejected. So there is a unidirectional causal relationship.

Vector Error Correction Model demonstrates the data is stationary, there exists a long-term relationship, VECM is exploited to find out the stability among our variable. The first table is for long-run relationships and the second one is for short-run relationships. In a long-run relationship (Table 5) a 1\% change in the Inflation Rate decreases the Real Exchange Rate by 3.76\%. With a 1\% change in an Interest Rate, there is a rise of 3.58\% in the Real Exchange Rate. The previous year's variance from long-run equilibrium is rectified at an adaptable speed of $0.001072 \%$. In the short run relationship (Table 6) a percent alteration in Inflation Rate is combined with a $0.02494 \%$ increase in the Real Exchange Rate. Finally, a percent change in Interest Rate is combined with $0.000470 \%$, an increase in the Real Exchange Rate.

Table 2. Johansen Test

\begin{tabular}{cccccccc}
\hline $\begin{array}{c}\text { Hypothesized } \\
\text { No. of CE(s) }\end{array}$ & Eigenvalue & $\begin{array}{c}\text { Trace } \\
\text { Statistic }\end{array}$ & $\begin{array}{c}\mathbf{0 . 0 5} \\
\text { Critical Value }\end{array}$ & Prob.** & $\begin{array}{c}\text { Max-Eigen } \\
\text { Statistic }\end{array}$ & $\begin{array}{c}\mathbf{0 . 0 5} \\
\text { Critical Value }\end{array}$ & Prob.** \\
\hline None $*$ & 0.28 & 33.98 & 29.80 & 0.02 & 19.13 & 21.13 & 0.09 \\
At most 1 $*$ & 0.19 & 14.85 & 15.49 & 0.06 & 12.00 & 14.26 & 0.11 \\
At most 2 & 0.05 & 2.85 & 3.84 & 0.09 & 2.86 & 3.84 & 0.09 \\
\hline
\end{tabular}

Source: Estimated. 
Table 3. Johansen Test (Normalized Co-integrating Coefficients)

\begin{tabular}{ccc}
\hline \multicolumn{2}{c}{ Normalized Co-integrating Coefficients(Standard Error in Parentheses) } \\
\hline Real Exchange Rate & Inflation Rate & Interest Rate \\
1.000000 & 0.000000 & 0.001353 \\
& & $(0.00749)$ \\
0.000000 & 1.000000 & -1.248314 \\
& & $(0.17547)$ \\
\hline D(Real Exchange Rate) & Adjustment Coefficients (Standard Error in Parentheses) & 0.003808 \\
& 0.182244 & $(0.00242)$ \\
D(Inflation Rate) & $(0.06706)$ & -0.032373 \\
& -3.638627 & $(0.12772)$ \\
D(Interest Rate) & $(3.53745)$ & 0.168857 \\
& -1.167823 & $(0.04904)$ \\
\hline
\end{tabular}

Source: Estimated.

Table 4. Pairwise Granger Causality Tests

Sample: 1958 - 2018

Lags: 2

\section{Null Hypothesis:}

Inflation Rate Does Not Granger Cause Real Exchange Rate

Real Exchange Rate Does Not Granger Cause Inflation Rate

Interest Rate Does Not Granger Cause Real Exchange Rate

Real Exchange Rate Does Not Granger Cause Interest Rate

Interest Rate Does Not Granger Cause Inflation Rate Inflation Rate Does Not Granger Cause Interest Rate

\section{Observation}

59

59
0.74488
0.4796
1.75029
0.1834

59

$\begin{array}{ll}1.18215 & 0.3144 \\ 5.84103 & 0.0051\end{array}$

Source: Estimated.

Table 5. Vector Error Correction Model (ECM)

\begin{tabular}{cc}
\hline Co-integrating Equation: & CointEq1 \\
\hline Real ExchangeRate (-1) & 1.000000 \\
Inflation Rate(-1) & -0.114070 \\
& $(0.03031)$ \\
Interest Rate(-1) & {$[-3.76323]$} \\
& 0.143748 \\
C & $(0.04008)$ \\
\hline
\end{tabular}

Source: Estimated. 
Table 6. Vector Error Correction Model (ECM)

\begin{tabular}{cccc}
\hline Error Correction & Real Exchange Rate & Inflation Rate & Interest Rate \\
\hline Cointegrating Equation 1 & 0.001072 & -0.343000 & -1.430359 \\
D [Real ExchangeRate (-2)] & 0.418318 & -2.175162 & 2.786982 \\
D [Inflation Rate (-2)] & 0.002494 & -0.102750 & -0.076934 \\
D [Interest Rate (-2)] & 0.000470 & -0.584453 & -0.025628 \\
C & 0.001740 & 1.119208 & -0.161856 \\
\hline
\end{tabular}

Source: Estimated.

CUSUM \& CUSUMQ shows that the Inflation Negatively Impacts on Real Exchange Rate although the Interest Rate Positively Impact on Real Exchange Rate. There are a strong short term and long-term relationship among variable and CUSUM \& CUSUM square (Figure 1 \& Figure 2) the test suggests that those data are stable over the year (1958-2018).

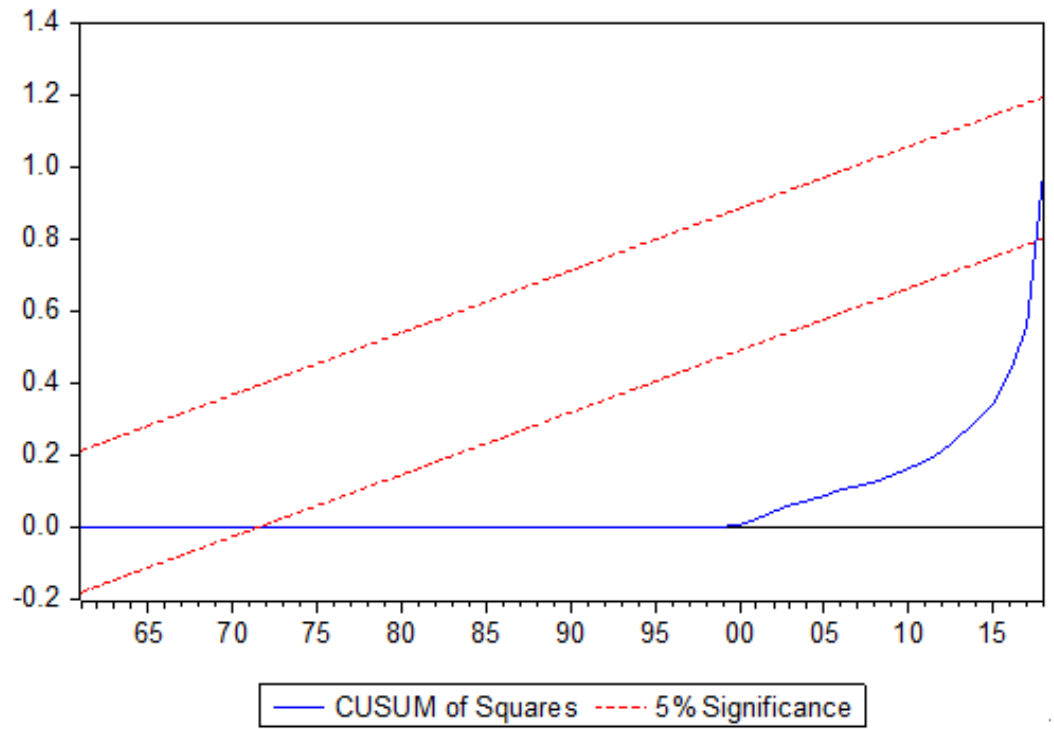

Figure 1. CUSUM Test (Source: Estimated).

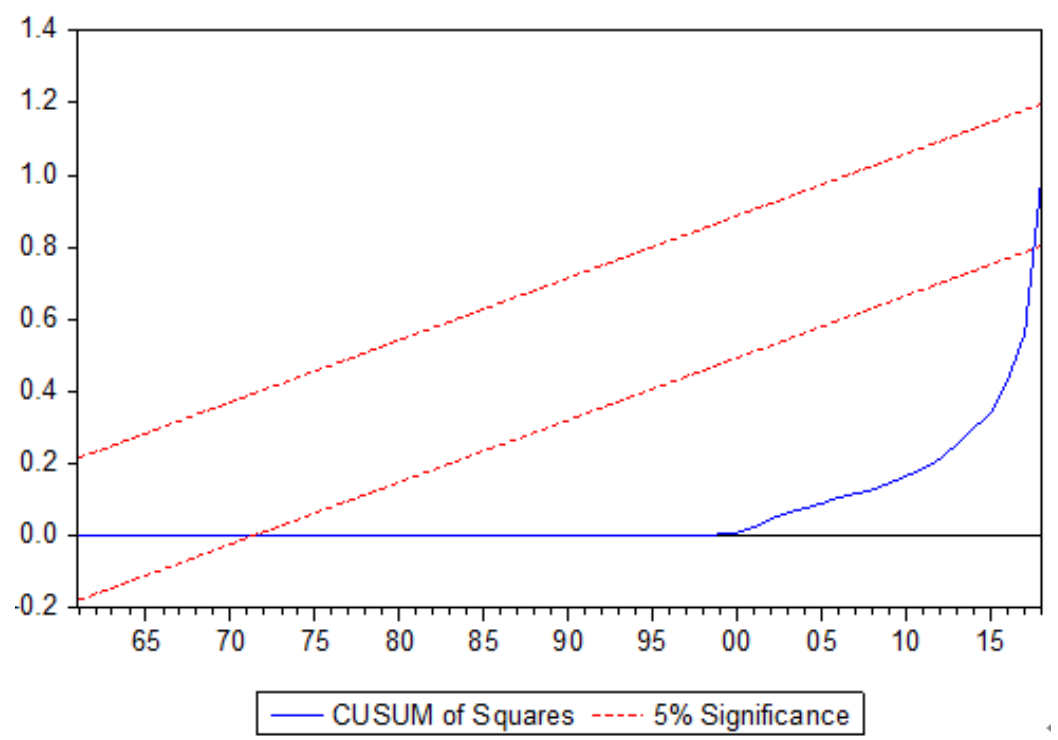

Figure 2. CUSUMQ Test (Source: Estimated). 


\section{Conclusion \& Policy Recommendations}

As a developed country Turkey has an emerging market economy. They have enough resources and a sustainable economic condition, but gradually their Real Exchange Rate is decreasing. This paper is based on their Purchasing Power Parity to determine their value of the currency and the factors which are responsible for decreasing the value of the currency. The results of this paper show that the Inflation Rate has a Negative Impact on their Real Exchange Rate and Interest Rate has a Positive Influence. The Inflation Rate has an independent causal relationship with Real Exchange Rate; however, Interest Rate has a unidirectional relationship. In addition to this long-run and short-run relationships also exist. Their Inflation Rate is slowly increasing which is the main factor for decreasing Real Exchange Rate. Interest Rate is also slowly decreasing. Interest Rate Positively Impacts on Real Exchange Rate, but for being gradually decreasing it is also an issue for decreasing Real Exchange Rate. This paper suggests there are still opportunities to improve their Real Exchange Rate by decreasing Inflation Rate and increasing the Interest Rate. For further research may be directed to consider the reason behind the increasing Inflation Rate and decreasing Interest Rates.

\section{References}

Alba, J. (2005). Purchasing Power Parity and Country. Singapore: Nanyang Technological University, 1-19.

Basher, S. (2007). Another Look at the Null of Stationary Real Exchange Rates: Panel Data with Structural Breaks and Cross-section Dependence. NewYork: Department of Economics, New York University.

Çağlayan, E. (2006). Satın alma gücü paritesinin geçerlili ğini sifir frekansta spektrum tahmincisine dayanan birim kök testleri ile incelenmes. Journal of Economics and Administrative Science, 121-137.

Chi-Wei Su, H.-L. C.-H. (2012). Purchasing power parity for BRICS: Linear and nonlinear unit root tests with stationary covariates. Applied Economics Letters, 1-5.

Cuestas, J. (2013). Purchasing power parity in OECD countries: Nonlinear unit root tests revisite. Economic Modelling, 343-346.

Dornbusch, R. (1985). Purchasing Power Parity. Cambridge: National Bureau of Economic Research.

Hüseyin Kalyoncu, F. K. (2010). The Validity of Purchasing Power Parity Hypothesis in Middle East and Northern Africa Countries. Romanian Journal of Economic Forecasting, 125-131.

Ismail Cevis, R. C. (2015). Kırılgan Beşlide Satın Alma Gücü Paritesi (SAGP) Hipotezinin Test Edilmesi. Journal of Yaşar University, 6381-6393.

Joseph D. Alba, D. P. (2005). An Empirical Investigation of Purchasing Power Parity (PPP) for Turkey. Journal of Policy Modeling, 989-1000.

P. K. Narayan, S. N. (2009). Evidence on PPP from a cointegration test with multiple structural breaks. Applied Economics Letters, 5-8.

Sayyan, H. (2005). Satınalma gücü paritesi: Vektör hata giderme modeli yaklaşimi. İktisat İşletme ve Finans, 96-104.

Tatoğlu, F. (2009). Reel Efektif Döviz Kurunun Durağanlığının Yapısal Kırılmalı Panel Birim Kök Testleri Kullanılarak Sınanması. Doğuş Üniversitesi Dergisi, 310-323.

Ümit, Ö. (2016). Stationarity of real exchange rates in the "fragile five": Analysis with structural breaks. International Journal of Economics and Finance, 254-270.

Yıldırım, D. (2017). Empirical investigation of purchasing power parity for Turkey: Evidence from recent nonlinear unit root tests. 39-45: Central Bank Review. 